\title{
Anticancer activity of some new series of 2-(substituted)amino-1,3-thiazole derivatives
}

\author{
Safyah B. Bakare \\ Faculty of Education, Shaqra University, Al Muzahimiyah, Shaqra, Riyadh Province, P.O. Box 90, Zip Code 11921,King- \\ dom Saudi Arabia \\ "Corresponding author: e-mail: safyahbakare@gmail.com
}

\begin{abstract}
A series of thiazole derivatives were synthesized and structurally elucidated by IR, ${ }^{1} \mathrm{H}$ NMR, ${ }^{13} \mathrm{C}$ NMR, mass and elemental analyses. The prepared compounds were screened for their cytotoxic activity against Leukemia HL-60 cell line. Compound $\mathbf{4 b}$ was considered as the most promising antitumor candidate among the tested compounds. Mechanism of action of compound $\mathbf{4 b}$ evaluated by flow cytometric assay revealed cell cycle arrest at G2/M phase and pre-G1 apoptosis. The ratio of apoptosis was also determined. Moreover, compound $\mathbf{4 b}$ increased the concentration of caspase 3 by 4 fold more than untreated control.
\end{abstract}

Keywords: Thiazole, Anticancer, Cell Cycle Analysis, Annexin V, FITC, Doxorubicin.

\section{INTRODUCTION}

Thiazole ring is a simple organic compound related to azoles. Thiazole molecules containing thiazole amine moiety exhibit interesting biological activities depending on the substitution pattern at the thiazole ring ${ }^{1}$. The thiazole compound was first described by Hantzch and waber in 1887 . The structure of thiazole compound was established by Popp in $1889^{2}$. The thiazole ring is a crucial part of vitamin B-1 (thiamine) and epothilone, thiazole dyes are used for dying cotton.

The rapid spread of cancer has sparked and intense worldwide search for new structure lead which may be of use in designing novel antitumor drugs. In this context, thiazoles and thiazoles linked to various heterocyclic rings through different linkages have recently attract great attention ${ }^{3-8}$. The antitumor activities of the natural antineoplastic antibiotics bleomycin, netropsin and thiazole netropsin have been reported ${ }^{9}$. Most of the aforementioned drugs have the thiazole carboxamide moiety as a common feature. Among these, triazofurin I was reported to possess potential anticancer activity.

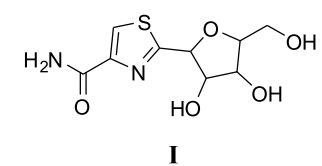

Keeping in view the importance of thiazole compounds and in continuation of our search on biologically active molecule ${ }^{10-12}$, we report the synthesis of simple thiazole derivatives by using p-chlorophenacylbromid and thiourea as starting materials. The synthesized $N$-substituted thiazole derivatives were considered a scaffold for further optimization to obtain a promising anticancer agents.

\section{RESULTS AND DISCUSSION}

\section{Chemistry}

The synthetic strategy adopted to obtain the target $\mathrm{N}$-substituted-1,3-thiazole derivatives are depicted in schemes 1 and 2.

The starting 4-(p-chlorophenyl)-2-aminothiazole (2) was synthesized from p-chlorophenacyl bromid with thiourea in ethanol in the presence of fused sodium acetate according to published procedure ${ }^{13}$. The 2-ami- nothiazole derivatives 2 was confirmed via its acetylation with acetic anhydride under reflux to give 5-(pchlorophenyl)-2-acetyl aminothiazole (3). FT-IR spectrum of compound 3 showed the expected absorption band at $3275(\mathrm{NH}), 1687(\mathrm{C}=\mathrm{O})$ and $1632(\mathrm{C}=\mathrm{N}) \mathrm{cm}^{-1}$. In the ${ }^{1} \mathrm{H}$ NMR spectrum of compound $\mathbf{3}$, the acetyl amino protons $\left(\mathrm{NHCOCH}_{3}\right)$ resonated at a singlet signal at $\delta 2.17\left(\mathrm{COCH}_{3}\right)$ and $\delta 12.85(\mathrm{NHCO}) \mathrm{ppm}$. The protons of aromatic and $\mathrm{H}-5$ of thiazole appeared as doublet of doublet from aromatic protons at $\delta 7.49$ and $\delta 7.91 \mathrm{ppm}$ and singlet at $\delta 7.66 \mathrm{ppm}$ for $\mathrm{H}-5$-thiazole ring (Fig. 1a). ${ }^{13} \mathrm{C}$ NMR spectrum of compound $\mathbf{3}$ showed two signals at $\delta 169.16$ and $22.96 \mathrm{ppm}$ corresponding to carbon atoms of acetyl amino $\left(\mathrm{NHCOCH}_{3}\right)$. The signals due to the aromatic and thiazole carbons were observed within the expected chemical shift at $8158.60,147.93,133.66$, 132.65, 129.21 (two carbons, 127.82 (two carbons) and $\delta 109.06$ ppm (Fig. 1b).

Ethyl $\beta$-aryl- $\beta$-[4-(p-chlorophenyl)-thiazole-2-ylamino]$\alpha$-cyano acrylate $\mathbf{4} \mathbf{a}, \mathbf{b}$ were obtained from the condensation of 5-(p-chlorophenyl)-2-aminothiazole with $\alpha, \beta$ unsaturated ester namely (Ethyl $\beta$-(p-hydroxyphenyl)- $\alpha$ cyano acrylate and Ethyl $\beta$-(p-methoxyphenyl)- $\alpha$-cyano acrylate) in ethanol in the presence of fused sodium acetate. The IR spectra of thiazole derivatives $\mathbf{4 a}, \mathbf{b}$ revealed the presence of stretching vibration for $\mathrm{NH}$ bands at $3285-3282 \mathrm{~cm}^{-1}$, in addition to absorption bands in the region of 2214-2210 $\mathrm{cm}^{-1}$ corresponding to cyano group $(\mathrm{CN})$, and bands in the region $1720-1714$ and $1634-1630 \mathrm{~cm}^{-1}$, which indicate the presence of $\mathrm{C}=\mathrm{O}$ and $\mathrm{C}=\mathrm{N}$ groups.

The ${ }^{1} \mathrm{H}$ NMR spectra of compounds $\mathbf{4}$ a,b showed a sharp two signals as triplet and quartet at $\delta 1.27-1.31$ and $84.26-4.30 \mathrm{ppm}$ due to the pattern of ethoxy group $\left(\mathrm{CH}_{3} \mathrm{CH}_{2} \mathrm{CO}-\right)$ and sharp singlet signals at $88.24-8.28$ ppm due to the NH protons. Protons of aromatic, olefinic and $\mathrm{H}-5$ of thiazole were observed within the chemical shift in region at $86.95-8.08 \mathrm{ppm}$ and exhibited the expected integral values. The protons of hydroxyl group $(\mathrm{OH})$ in compound 4a appeared as broad singlet signal at $\delta 10.85 \mathrm{ppm}$, while the protons of methoxy group $\left(\mathrm{OCH}_{3}\right)$ in compound $\mathbf{4} \mathbf{b}$ appeared as a sharp signal at $\delta 3.86$ ppm (Fig 2). 


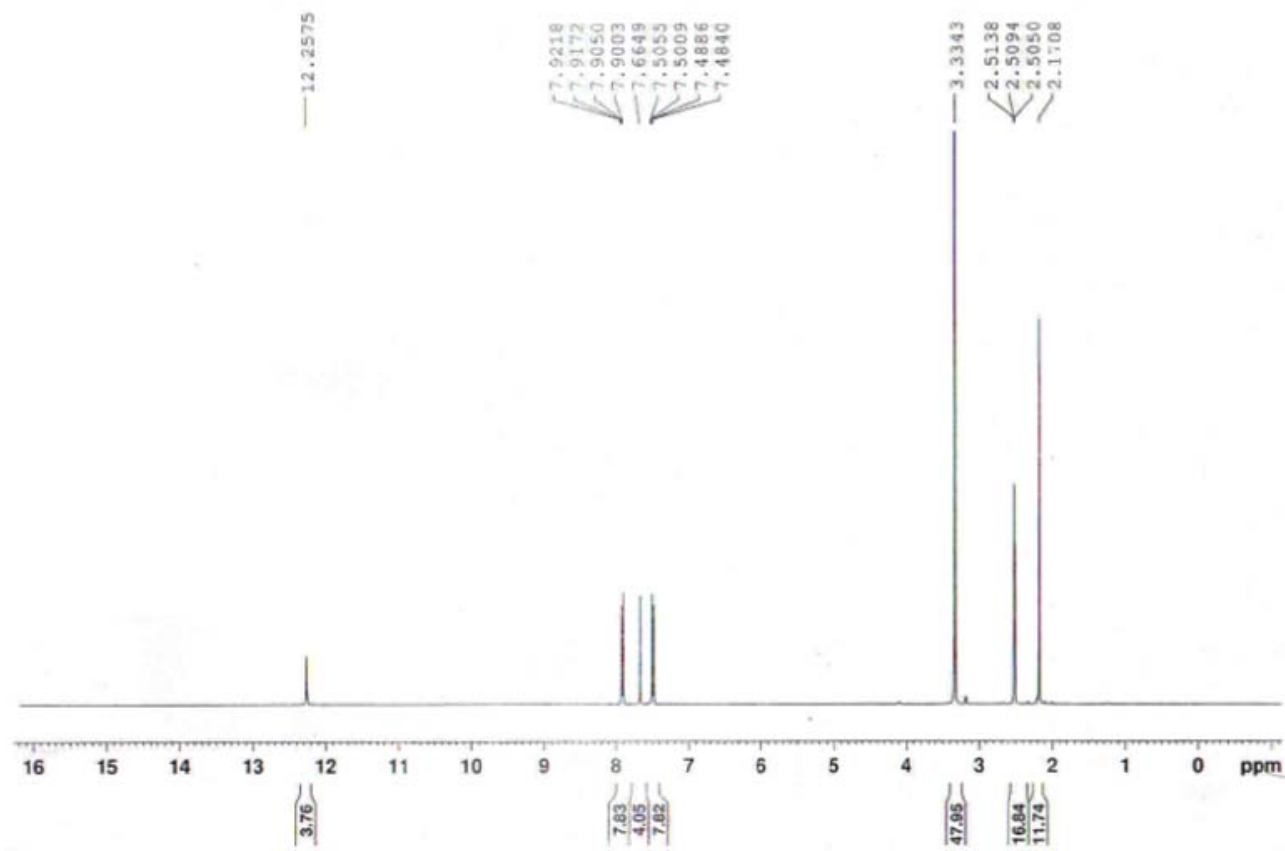

Figure 1a. ${ }^{1} \mathrm{H}$ NMR Spectrum of compound $\mathbf{3}$

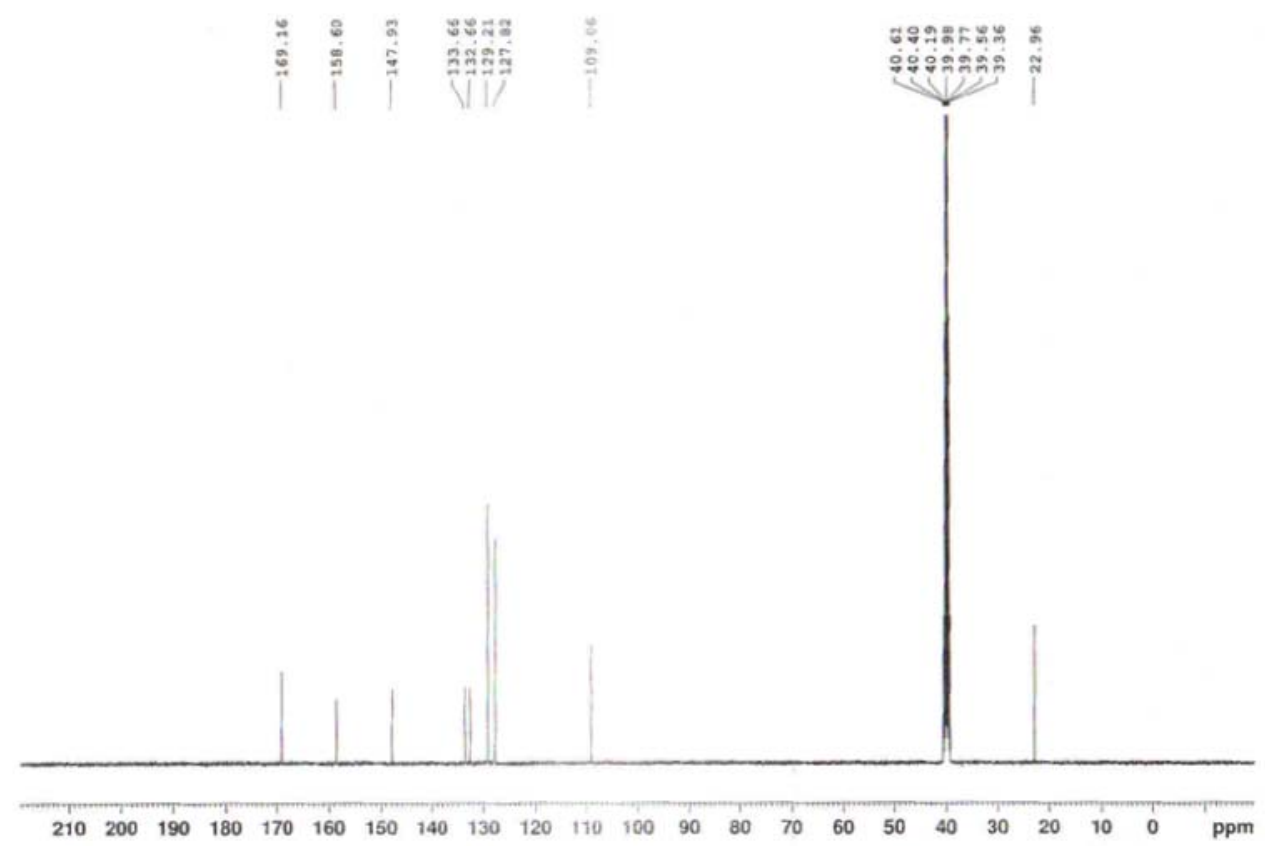

Figure 1b. ${ }^{13} \mathrm{C}$ NMR Spectrum of compound $\mathbf{3}$

Structure of ethyl $\beta$-(p-hydroxyphenyl)- $\beta$-[4-(pchlorophenyl)-thiazole-2-ylamino]- $\alpha$-cyano acrylate (4a) was confirmed via its transformation into ethyl $\beta$-(p-acetoxyphenyl)- $\beta$-[4-(p-chlorophenyl)-thiazole-2ylacetylamino]- $\alpha$-cyano acrylate (5) by refluxing with acetic anhydride.

Reaction of 4-(p-chlorophenyl)-2-aminothiazole with cinnamic acid in pyridine under reflux was expected to give $\beta$-phenyl- $\beta$-[4-(p-chlorophenyl)thiazole-2-ylamino] acylic acid (6), but only $N$-[4-(p-chlorophenyl)thiazol-1-yl] cinnamide (7) was yielded. FT-IR spectrum of compound 7 showed absorption bands at 3283, 1682 and $1630 \mathrm{~cm}^{-1}$ for $\mathrm{NH}, \mathrm{C}=\mathrm{O}$ and $\mathrm{C}=\mathrm{N}$ groups, respectively. In the ${ }^{1} \mathrm{H}$ NMR spectrum of compound 7 , the amide proton (NHCO) resonated as broad singlet signal at $\delta 12.40$ ppm. The proton signals of aromatic, olefinic and H-5 of thiazole ring are observed in the expected region at 86.51-7.82 ppm (Fig. 3).
Condensation of thiazole derivative 7 with 2-hydroxy benzaldehyde in the presence of piperidine as catalyst under fusion led to the formation of $N$-(o-hydroxyphenyl, hydroxy) methyl, $N$-(4-(p-chlorophenyl)thiazol-2-yl) cinnamide (8). The structure of $\mathbf{8}$ was established via its acetylation with acetic anhydride to give $N$-(o-acetoxyphenyl, acetoxy) methyl- $N$-(4-(p-chlorophenyl)thiazol-2-yl) cinnamide (9). FT-IR spectrum of compound 9 showed the expected absorption bands at 1766, 1692 and 1632 $\mathrm{cm}^{-1}$ for carbonyl and $\mathrm{C}=\mathrm{N}$ groups, respectively. The absence of absorption band corresponding to hydroxyl group stretching frequency. In the ${ }^{1} \mathrm{H}$ NMR spectrum of compound 9 showed three singlet signals at $\delta 2.14,2.17$ and $5.91 \mathrm{ppm}$ due to the protons of two methyl for the acetyl groups and O-CH-N group. The protons of aromatic, olifinic and H-5 of thiazole ring appeared in the region at $87.15-7.92 \mathrm{ppm}$ as multiplet signals (Fig. 4). 


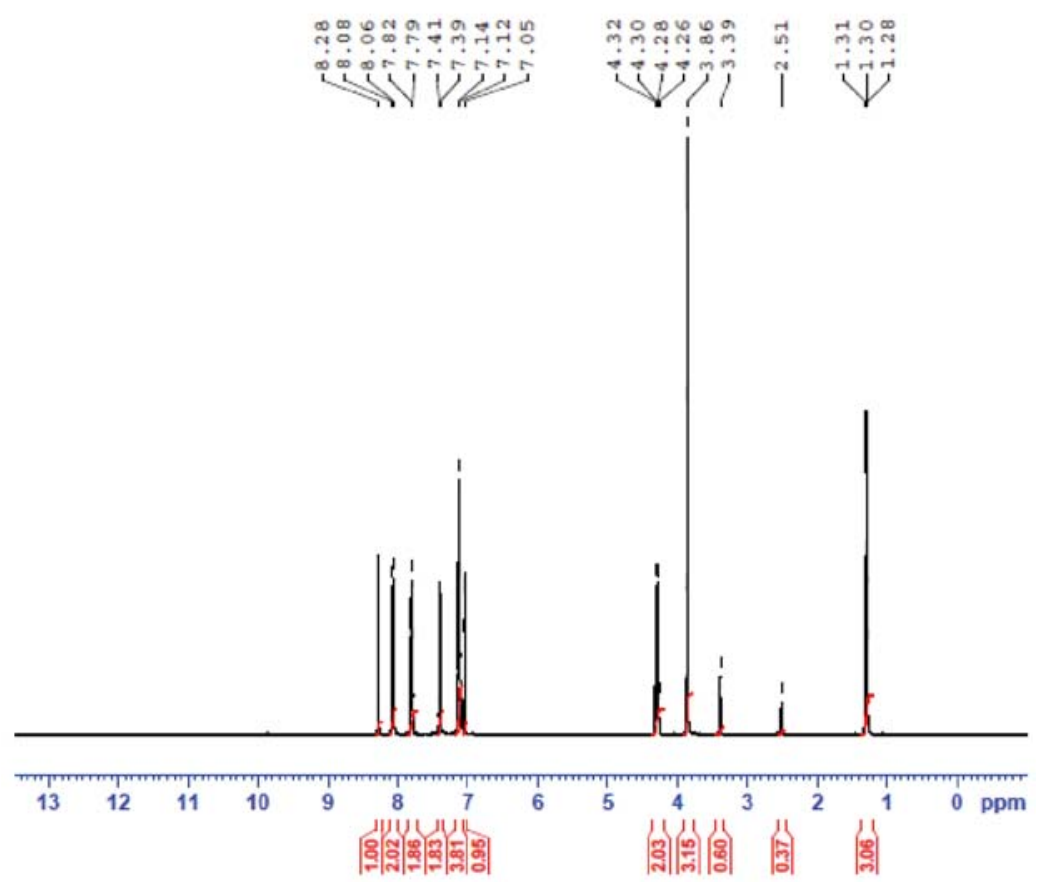

Figure 2. ${ }^{1} \mathrm{H}$ NMR Spectrum of compound $\mathbf{4 b}$

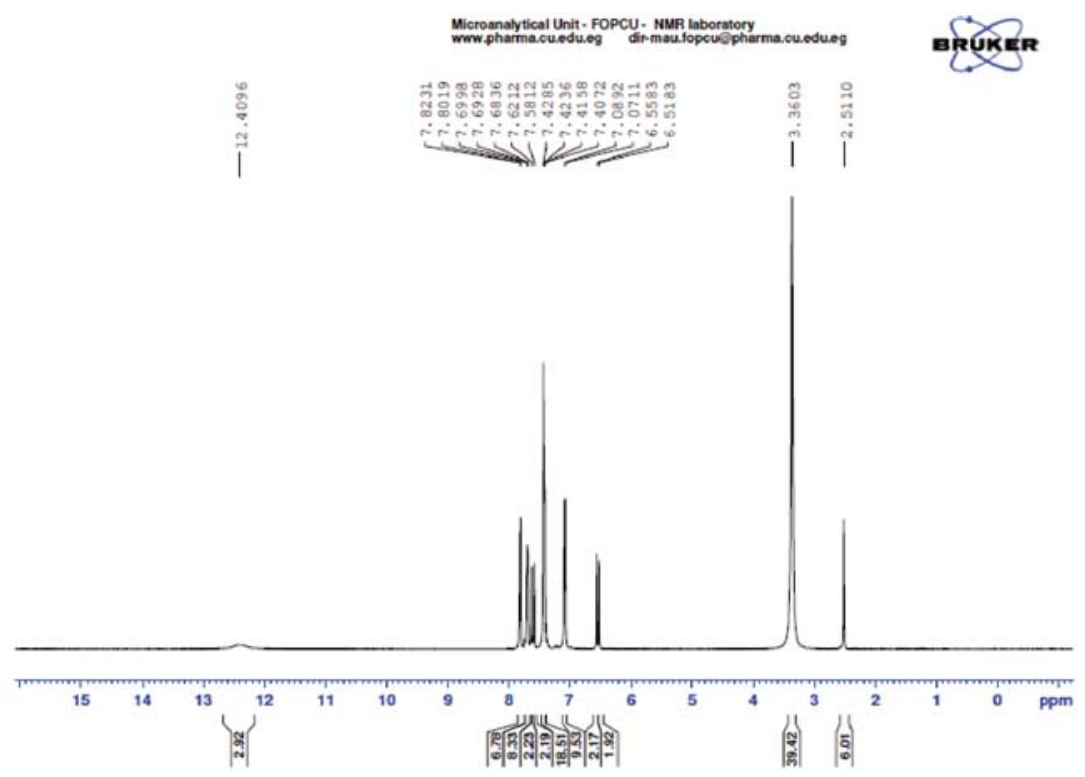

Figure 3. ${ }^{1} \mathrm{H}$ NMR Spectrum of compound 7

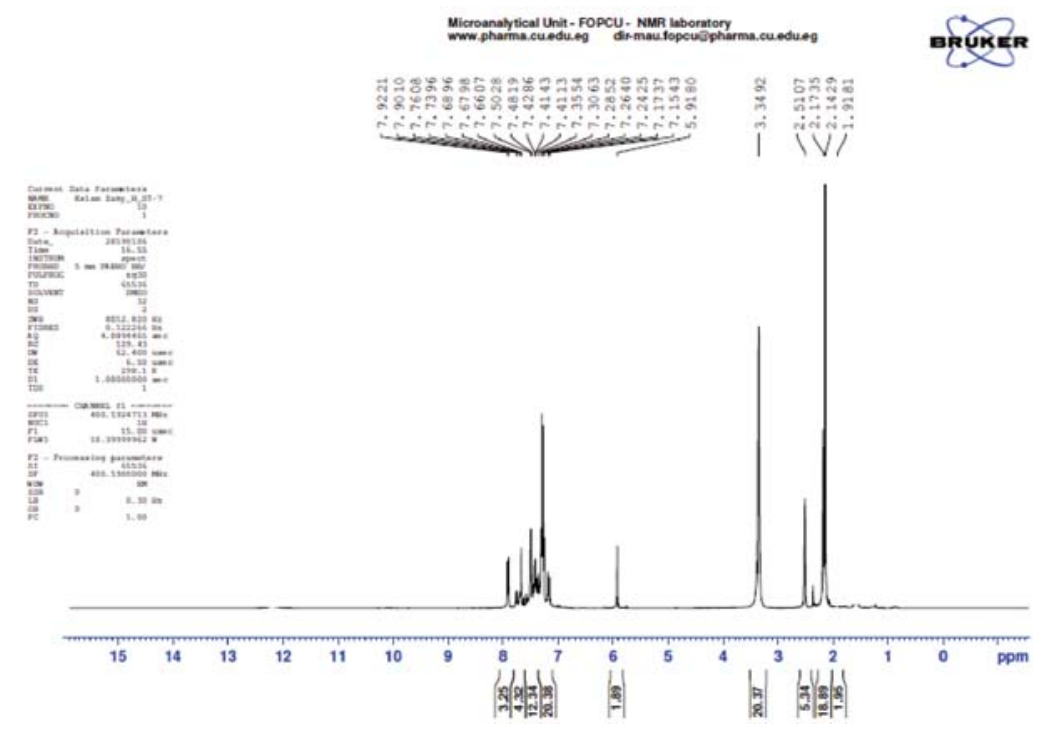

Figure 4. ${ }^{1} \mathrm{H}$ NMR Spectrum of compound 9 


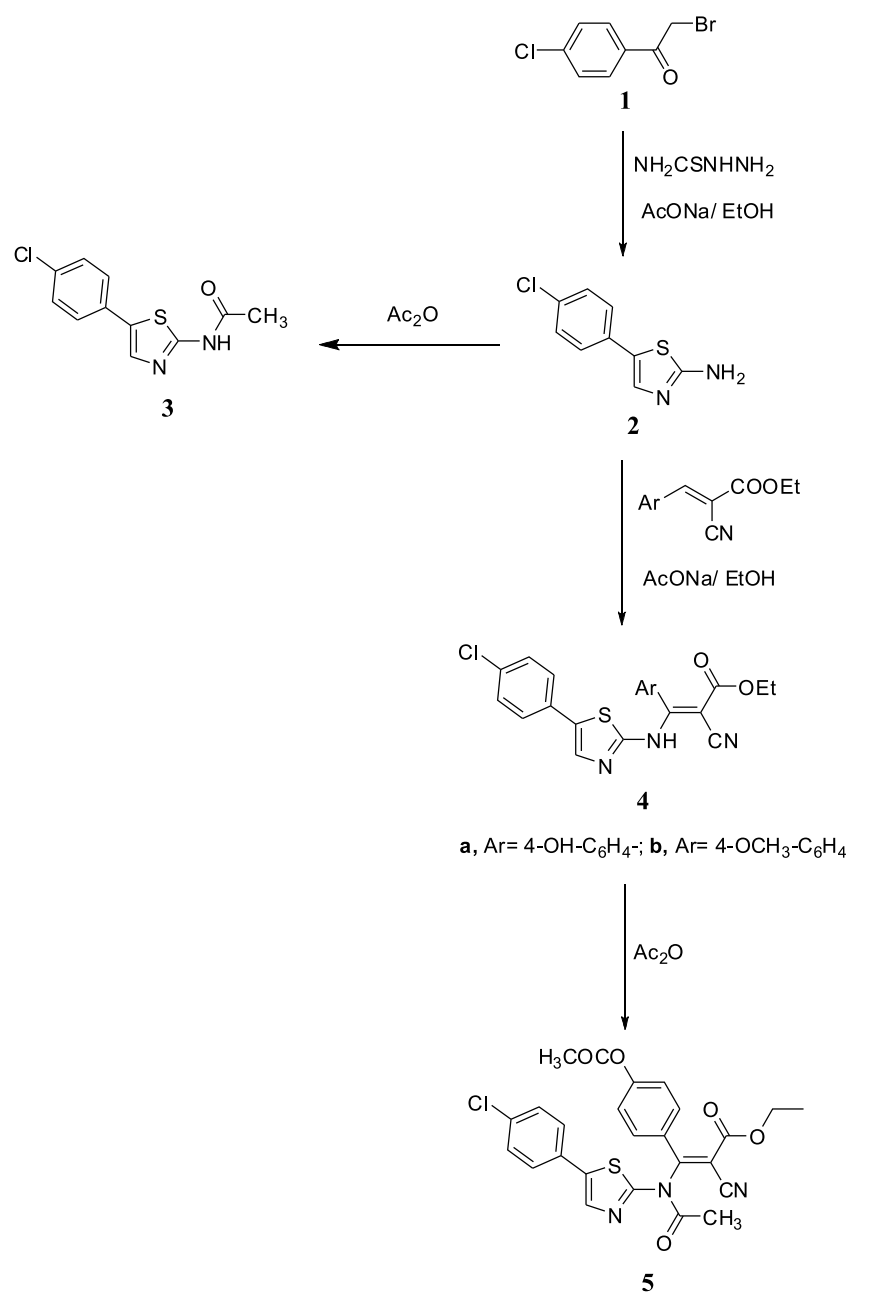

Scheme 1. Synthesis of 2-N-(substituted) amino thiazole derivatives (3-5).

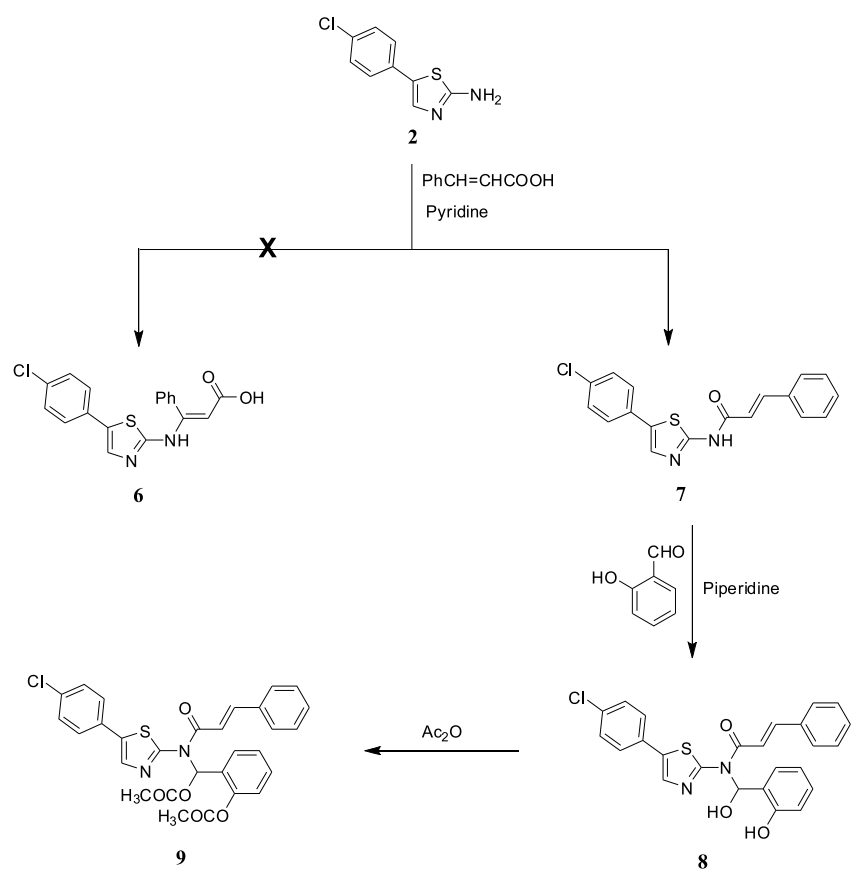

Scheme 2. Synthesis of 1,3-thiazole derivatives (7-9).

\section{Evaluation of biological activity}

\section{In vitro cytotoxic activity against Leukemia HL-60 cell line}

In order to examine the anticancer activity of the prepared thiazole derivatives, the effect of the synthesized compounds on the viability of Leukemia HL-60 cell line was measured using colorimetric MTT assay after $48 \mathrm{~h}$ of incubation. The percentage of cell viability of thiazole derivatives and reference compound are presented in Table 1 and represented graphically in Fig. 5. The reference compound in our assay is Doxorubicin (Dox). As shown in Table 1 and Fig. 5, compounds 4a, 4b and 7 showed significant anti-proliferative activity compared to the reference compound Dox against HL-60 cell line. Overall, derivatives of Ethyl $\beta$-aryl- $\beta$-[4-(p-chlorophenyl)thiazole-2-ylamino]- $\alpha$-cyano acrylate $\mathbf{4 a , b}$ were found to have superior anti-cancer activity compared to the other thiazole derivatives. Among the thiazole derivatives compound Ethyl $\beta$-(4-methoxyphenyl)- $\beta$-[4-(p-chlorophenyl)thiazole-2-ylamino]- $\alpha$-cyano acrylate $(\mathbf{4 b})$ was found to be superior to the other thiazole derivatives in terms of anti-cancer activity with $\mathrm{IC}_{50}$ value of $1.3 \pm 0.29 \mu \mathrm{M}$.

Table 1. In vitro antitumor activity of 1,3-thiazole derivatives 3-9 over Leukemia HL-60 cell line. Data are expressed as the mean \pm three experiments

\begin{tabular}{|c|c|}
\hline Compound No. & IC50 values $[\mu \mathrm{M}]$ \\
\cline { 2 - 2 } & $\mathrm{HL}-60$ \\
\hline 3 & $42.1 \pm 1.08$ \\
\hline $4 \mathrm{a}$ & $8.9 \pm 0.48$ \\
\hline $4 \mathrm{~b}$ & $1.3 \pm 0.29$ \\
\hline 5 & $58.3 \pm 0.93$ \\
\hline 7 & $7.3 \pm 0.35$ \\
\hline 8 & $13.6 \pm 0.86$ \\
\hline 9 & $82.4 \pm 1.62$ \\
\hline Dox & $3.01 \pm 0.07$ \\
\hline
\end{tabular}

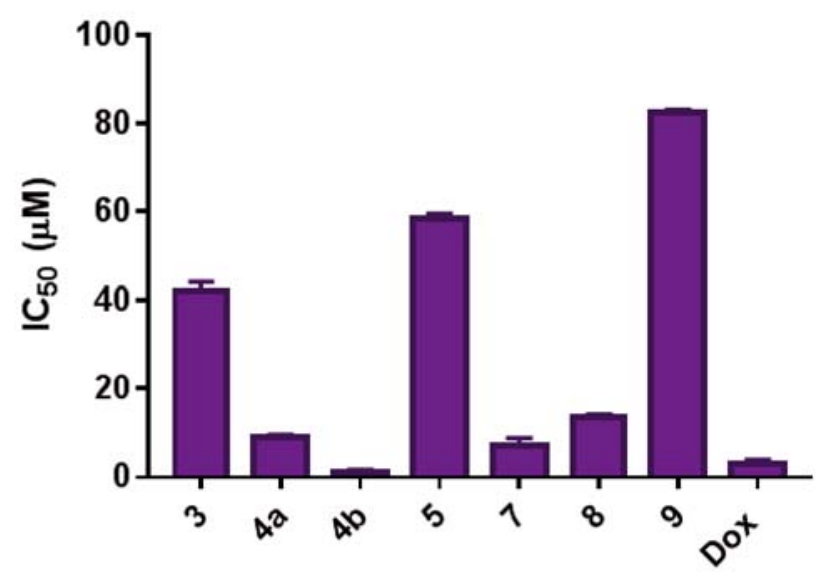

Figure 5. $\mathrm{IC}_{50}$ values $(\mu \mathrm{M})$ noted for 1,3-thiazole derivatives and Doxorubicin against leukemia HL-60 cell line

\section{Cell cycle analysis}

Due to the importance of the cell cycle in the process of tumor cell proliferation, HL-60 cell growth inhibition due to cell cycle arrest using DNA flow cytometric assay for $48 \mathrm{~h}$ was evaluated ${ }^{3}$. In this assay, HL-60 cells were treated with compound $\mathbf{4 b}$ at its $\mathrm{IC}_{50}$ concentration value for $48 \mathrm{~h}$. It is evident from Fig. 6, compound $\mathbf{4 b}$ showed G2/M cell cycle arrest compared with untreated control. Compound $\mathbf{4 b}$ showed $37.08 \%$ of cells in G2/M phase in comparison with the untreated cells which had $7.13 \%$. Moreover, compound $\mathbf{4 b}$ revealed G0 phase arrest marked by appearance of peak at G0 phase of the cell cycle distribution profile which indicate HL-60 cell apoptosis. In conclusion, compound $\mathbf{4 b}$ showed cell cycle 


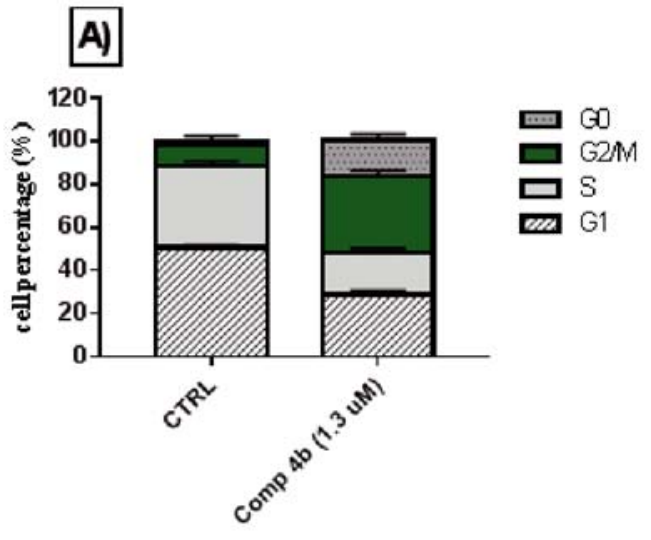

B)

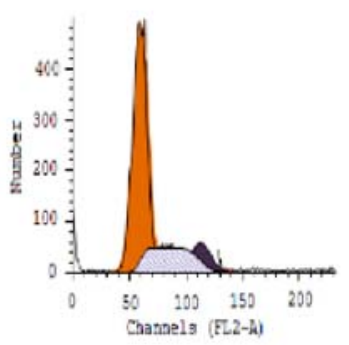

C)

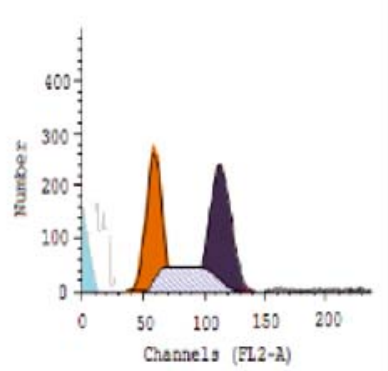

Figure 6. Effect of compound $\mathbf{4 b}$ on the HL-60 cell line determined by flow cytometry analysis after $48 \mathrm{~h}$ of incubation. A) Graphical presentation, B) Cell cycle analysis of control group, C) Cell cycle analysis of compound $\mathbf{4 b}$

arrest at $\mathrm{G} 2 / \mathrm{M}$ phase with apoptosis inducing activity in HL-60 treated cells.

\section{Annexin V-FITC Staining assay}

Several thiazole derivatives have been reported in the literature as apoptosis inducer in several tumor cell line ${ }^{\mathbf{1 4}}$. Therefore apoptosis ratio was determined in HL-60 cells for $48 \mathrm{~h}$. In this study, HL-60 cells were incubated with compound 4 bfor $48 \mathrm{~h}$ and then stained with Annexin V-FITC followed by flow cytometry assay. The results in this assay (Fig. 7) showed that, compound $\mathbf{4 b}$ could enhance the early apoptosis stage by $4.88 \%$ compared with the untreated cells. Moreover, compound $\mathbf{4 b}$ could increase the late apoptosis stage with $7.7 \%$ in comparison with the control group. These data indicated the involvement of apoptosis in inhibition of HL-60 cells induced by compound $\mathbf{4 b}$.

\subsubsection{Caspase 3 assay}

To ensure that, compound $\mathbf{4 b}$ induce apoptosis, compound $\mathbf{4 b}$ was screened for its ability to activate caspase 3. Leukemia HL-60 cell line was treated with compound $\mathbf{4 b}$ at its $\mathrm{IC}_{50}$ concentration dose value and caspase 3 concentration was measured using ELISA assay. From the obtained data in Fig. 8 it was observed that compound $\mathbf{4 b}$ could enhance the concentration of caspase 3 as concluded from the optical density values by 4.55 - fold compared with the untreated control. In conclusion, compound $\mathbf{4 b}$ may induce apoptosis through activation of caspade 3 .
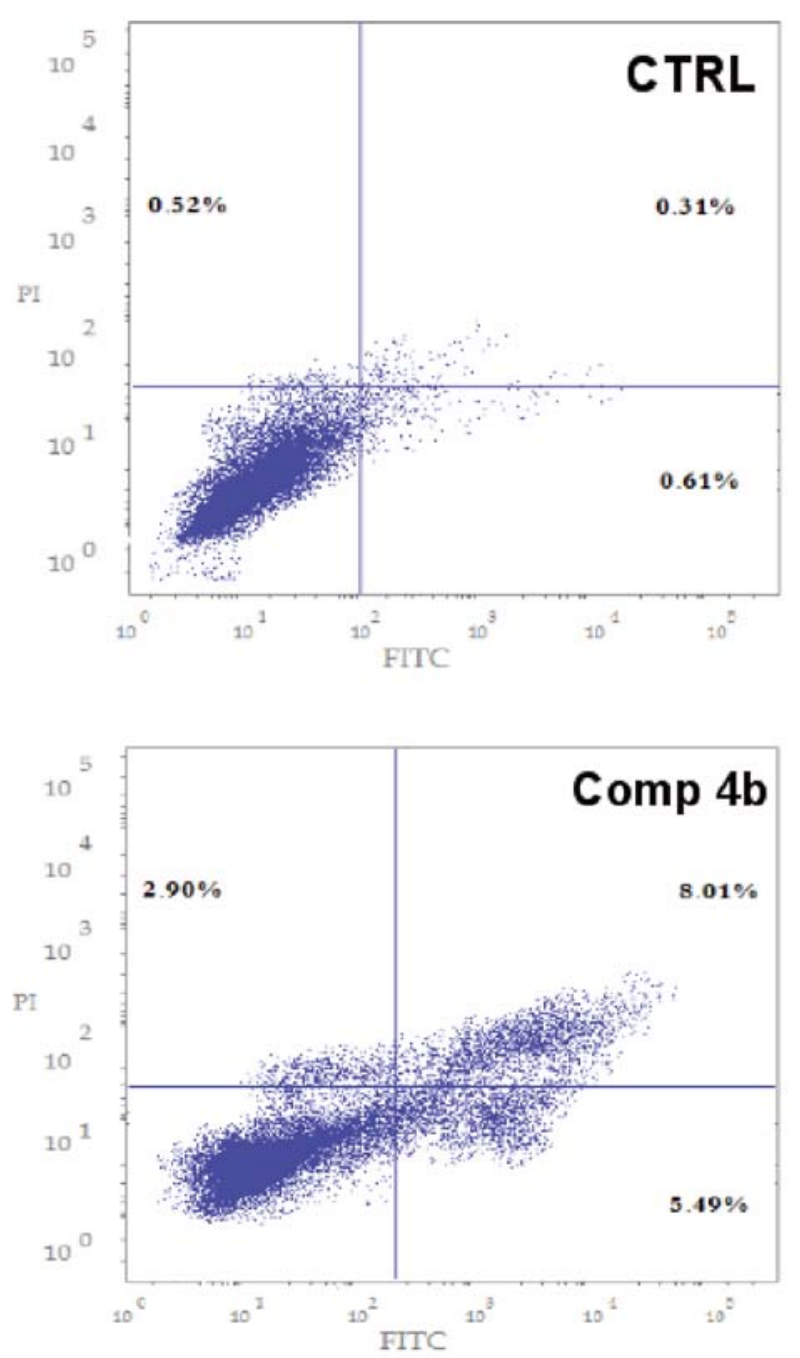

Figure 7. Annexin V-FITC of compound $\mathbf{4 b}$ at its $\mathrm{IC}_{50}$ concentration dose value $(\mu \mathrm{M})$ compared to untreated control cells

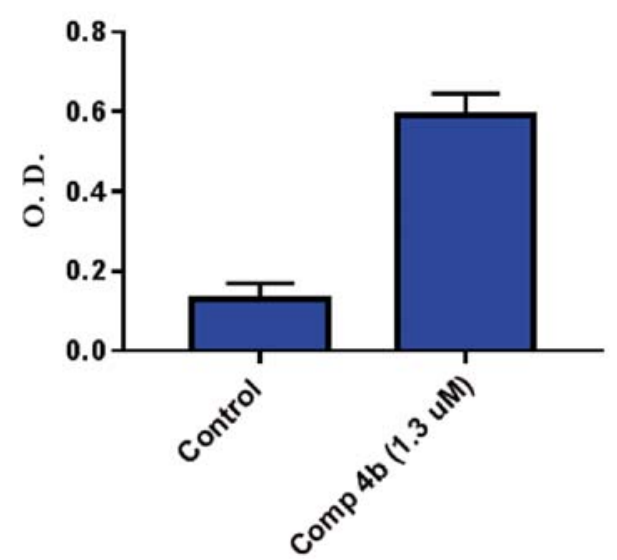

Figure 8. Effect of compound $\mathbf{4 b}$ on the caspase 3 compared to untreated control

\section{CONCLUSION}

In the present synthesis of 4-(p-chlorophenyl)-2-amino-1,3-thiazole (2) by the reaction of p-chlorophenacyl bromide with thiourea. Treatment of 2-amino thiazole with $\alpha, \beta$-unsaturated ester and acid in different condition led to the formation of 2-(substituted)amino thiazole derivatives 3, 4 and 7. Condensation of compound 7 with 2-hydroxy benzaldehyde yielded the corresponding $N$ -(o-hydroxyphenyl, hydroxy) methyl- $N$-(4-p-chlorophenyl 
thiazole-2-yl)-cinnamide (8). Acetylation of compound $\mathbf{4}$ and $\mathbf{8}$ with acetic anhydride give diacetyl derivatives 5 and 9. The structure of the synthesized derivatives 2-9 were confirmed by IR, ${ }^{1} \mathrm{H}$ NMR, ${ }^{13} \mathrm{C}$ NMR, mass and elemental analyses. All the synthesized thiazole derivatives were screened for their cytotoxic activity against Leukemia HL-60 cell line. Compound 4b was considered as the most promising antitumor compound among the tested compounds. Mechanism of action of compound $\mathbf{4 b}$ evaluated by flow cytometric assay revealed cell cycle arrest at $\mathrm{G} 2 / \mathrm{M}$ phase and pre-G1 apoptosis. The ratio of apoptosis was also determined. Moreover, compound $\mathbf{4 b}$ increased the concentration of caspase 3 by more than 4 fold compared with untreated control. The synthesized $N$-substituted thiazole derivatives were considered a scaffold for further optimization to obtain a promising anticancer agents.

\section{EXPERIMENTAL}

\section{Chemistry}

${ }^{1} \mathrm{H}$ NMR (400 MHz) and ${ }^{13} \mathrm{C}$ NMR (100 MHz) spectra were run with a Brucker 400 DRX-Avance NMR spectrometer using DMSO- $\mathrm{d}_{6}$ as solvent- chemical shifts are reported on ppm downfield from internal tetramethylsilane and are given in the scale. The IR data were obtained with a Schimadzu 470 spectrometer. Melting point were measured using open capillary tubes on a melt-temp melting point apparatus and are uncorrected. Mass spectral data were obtained with Probe Agilent MSD-5979 mass spectrometer. The elemental analysis was carried out on a Perkin-Elmer $2400 \mathrm{CHN}$ analyzer. All chemicals were purchased from Aldrich chemical company, Merk and Fluka.

\section{Synthesis of 4-(p-chlorophenyl)-2-aminothiazole (2)}

An equimolar mixture of p-chlorophenacyl bromide (1, $0.01 \mathrm{~mol})$, thiourea $(0.01 \mathrm{~mol})$ and fused sodium acetate $(0.03 \mathrm{~mol})$ in absolute ethanol $(50 \mathrm{~mL})$ was heated under reflux for $2 \mathrm{~h}$. The reaction mixture was cooled and poured into water, then the precipitate formed was filtered off, washed with water, dried. Finally, the product was crystallized from ethanol to give 2 .

Yellow crystals, yield $83 \%$, m.p $178-180^{\circ} \mathrm{C}$. IR (KBr): 3335-3282 $\left(\mathrm{NH}_{2}\right), 1635(\mathrm{C}=\mathrm{N}) \mathrm{cm}^{-1} .{ }^{1} \mathrm{H}$ NMR (DMSO$d_{6}$ ) $\delta: 4.09$ (br. s, $2 \mathrm{H}, \mathrm{NH}_{2}$ ), 7.20 (s, 1h, H-5 of thiazole ring), 7.47 (d, 2H, Ar-H), 7.75 (d, 2H, Ar-H) ppm. MS: $\mathrm{m} / \mathrm{z}(\%)=212\left(\mathrm{M}^{+}+2,33.86\right), 210\left(\mathrm{M}^{+}, 100\right)$ Anal. Calcd. For $\mathrm{C}_{9} \mathrm{H}_{7} \mathrm{~N}_{2} \mathrm{ClS}$ (210): C, 51.31; H, 3.35; N, 13.30 . Found: C, 51.23; H, 3.13; N, 13.19.

Synthesis of Ethyl $\beta$-aryl- $\beta$-[4-(p-chlorophenyl)-thiazole2-ylamino]- $\alpha$-cyano acrylate $4 a, b$

A mixture of 4-(p-chloro phenyl)-2-aminothiazole (2, $0.01 \mathrm{~mol}), \alpha, \beta$-unsaturated ester $(0.01 \mathrm{~mol})$ and fused sodium acetate $(0.03 \mathrm{~mol})$ in absolute ethanol $(50 \mathrm{ml})$ was heated under reflux for $4 \mathrm{~h}$ the reaction mixture was cooled and poured into water. The product formed was collected by filtration, washed with water, dried and purified by crystallization from ethanol to give 4 .
Ethyl $\beta$-(4-hydroxyphenyl)- $\beta$-[4-(p-chlorophenyl)thiazole-2-ylamino]- $\alpha$-cyano acrylate (4a)

Yellow crystals, yield $78 \%$, m.p $125-127^{\circ} \mathrm{C}$. IR (KBr): $3437(\mathrm{OH}), 3286(\mathrm{NH}), 2232(\mathrm{CN}), 1718(\mathrm{C}=\mathrm{O}), 1633$ $(\mathrm{C}=\mathrm{N}), 1174,1089(\mathrm{C}-\mathrm{O}) \mathrm{cm}^{-1} \cdot{ }^{1} \mathrm{H}$ NMR (DMSO-d $\left.d_{6}\right)$

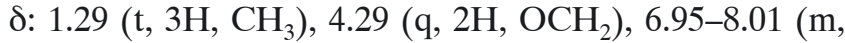
$9 \mathrm{H}, \mathrm{Ar}-\mathrm{H}$ and $\mathrm{H}-5$ of thiazole ring), 8.24 (s, 1H, NH), 10.85 (br. s, $1 \mathrm{H}, \mathrm{OH}) \mathrm{ppm}$. MS: $\mathrm{m} / \mathrm{z}(\%)=427\left(\mathrm{M}^{+}+2\right.$, 1.32), $425\left(\mathrm{M}^{+}\right.$, 5.20) Anal. Calcd. For $\mathrm{C}_{21} \mathrm{H}_{16} \mathrm{~N}_{3} \mathrm{ClO}_{3} \mathrm{~S}$ (425): C, 59.22; H, 3.79; N, 9.87. Found: C, 59.09; H, 3.48; N, 9.59 .

Ethyl $\beta$-(4-methoxyphenyl)- $\beta$-[4-(p-chlorophenyl)thiazole-2-ylamino]- $\alpha$-cyano acrylate $(4 \mathrm{~b})$

Yellow crystals, yield $76 \%$, m.p $118-120^{\circ} \mathrm{C}$. IR (KBr): $3283(\mathrm{NH}), 2214(\mathrm{CN}), 1715(\mathrm{C}=\mathrm{O}), 1633(\mathrm{C}=\mathrm{N}), 1605$, $1585(\mathrm{C}=\mathrm{C}), 1126,1015(\mathrm{C}-\mathrm{O}) \mathrm{cm}^{-1} .{ }^{1} \mathrm{H}$ NMR (DMSO$\left.d_{6}\right) \delta: 1.30\left(\mathrm{t}, 3 \mathrm{H}, \mathrm{CH}_{3}\right), 3.86\left(\mathrm{~s}, 3 \mathrm{H}, \mathrm{CH}_{3}\right), 4.30(\mathrm{q}, 2 \mathrm{H}$, $\left.\mathrm{OCH}_{2}\right), 7.05-8.08(\mathrm{~m}, 9 \mathrm{H}, \mathrm{Ar}-\mathrm{H}$ and $\mathrm{H}-5$ of thiazole ring), $8.28(\mathrm{~s}, 1 \mathrm{H}, \mathrm{NH}) \mathrm{ppm}$. MS: $\mathrm{m} / \mathrm{z}(\%)=441\left(\mathrm{M}^{+}+2\right.$, 1.10), $439\left(\mathrm{M}^{+}, 4.33\right)$ Anal. Calcd. For $\mathrm{C}_{22} \mathrm{H}_{18} \mathrm{~N}_{3} \mathrm{ClO}_{3} \mathrm{~S}$ (439): C, 60.07; H, 4.12; N, 9.55. Found: C, 60.02; H, $3.83 ; \mathrm{N}, 9.38$.

Synthesis of $\mathrm{N}$-[4-(p-chlorophenyl)thiazol-1-yl] cinnamide (7)

An equimolar mixture of 4-(p-chloro phenyl)-2-aminothiazole $(2,0.01 \mathrm{~mol})$, and cinnamic acid $(0.01 \mathrm{~mol})$ in pyridine $(30 \mathrm{~mL})$ was heated under reflux for $6 \mathrm{~h}$. the reaction mixture was cooled and poured into water, and neutralized with dilute hydrochloric acid (2\%). The product formed was collected by filtration, washed with water, dried and purified by crystallization with ethanol to give compound 7 .

Yellow crystals, yield $72 \%$, m.p $110-112^{\circ} \mathrm{C}$. IR (KBr): $3283(\mathrm{NH}), 2214(\mathrm{CN}), 1682(\mathrm{C}=\mathrm{O}), 1630(\mathrm{C}=\mathrm{N}), 1601$, $1534(\mathrm{C}=\mathrm{C}) \mathrm{cm}^{-1} .{ }^{1} \mathrm{H}$ NMR (DMSO- $\left.d_{6}\right) \delta: 6.51-7.82(\mathrm{~m}$, $12 \mathrm{H}, \mathrm{Ar}-\mathrm{H}, \mathrm{H}$ olefinic and $\mathrm{H}-5$ of thiazole ring), 12.40 (br. s, 1H, NHCO) ppm. MS: $\mathrm{m} / \mathrm{z}(\%)=342\left(\mathrm{M}^{+}+2\right.$, 2.30), $340\left(\mathrm{M}^{+}\right.$, 7.31) Anal. Calcd. For $\mathrm{C}_{18} \mathrm{H}_{13} \mathrm{~N}_{2} \mathrm{ClOS}$ (439): C, 63.43; H, 3.84; N, 8.22. Found: C, 63.32; H, $3.56 ; \mathrm{N}, 8.07$.

Synthesis of $N$-(o-hydroxyphenyl, hydroxy) methyl, $N$-(4-(p-chlorophenyl)thiazol-2-yl) cinnamide(8).

A mixture of 7 (0.01 mol), 2-hydroxybenzaldehyde $(0.01 \mathrm{~mol})$ and piperidine $(2 \mathrm{~mL})$ was fused on hot plate for $10-15 \mathrm{~min}$, then added $50 \mathrm{~mL}$ ethanol. The reaction mixture was heated under reflux for $4 \mathrm{~h}$, then cooled, poured into water and neutralized with dilute hydrochloric acid (2\%). The separated solid product was filtered off, washed with water, dried and crystallized from ethanol to give $\mathbf{8}$.

Orange crystals, yield $63 \%$, m.p $135-137^{\circ} \mathrm{C}$. IR (KBr): 3450-3300 (br. OH), $1685(\mathrm{C}=\mathrm{O}), 1632(\mathrm{C}=\mathrm{N}), 1605$, $1585(\mathrm{C}=\mathrm{C}), 1178,1038(\mathrm{C}-\mathrm{O}) \mathrm{cm}^{-1} .{ }^{1} \mathrm{H}$ NMR (DMSO$\left.d_{6}\right) \delta:$ 6.09-8.02 (m, 17h, Ar-H, olefinic and $\mathrm{H}-5$ of thiazole ring), 9.72 (s, 1H, OH), 11.57 (br. s, 1H, OH) ppm. MS: $\mathrm{m} / \mathrm{z}(\%)=462\left(\mathrm{M}^{+}, 100\right)$ Anal. Calcd. For $\mathrm{C}_{25} \mathrm{H}_{19} \mathrm{~N}_{2} \mathrm{ClO}_{3} \mathrm{~S}$ (462): C, 64.86; H, 4.14; N, 6.05. Found: C, 64.74; H, 4.02; N, 5.83. 


\section{General procedure for acetylation reaction}

A solution of $\mathbf{2 , 4}$ and $\mathbf{8}(0.01 \mathrm{~mol})$ in acetic anhydride $(15 \mathrm{~mL})$ was heated under reflux for $2 \mathrm{~h}$, the reaction mixture was allowed to cool to room temperature, poured into water and left for $24 \mathrm{~h}$. the solid formed was filtered off, washed with water and dried. Finally the product was crystallized from ethanol to give $\mathbf{3 , 5}$ and $\mathbf{9}$.

\section{5-(p-chlorophenyl)-2-acetyl aminothiazole (3)}

Pale yellow crystals, yield $74 \%$, m.p $205-207^{\circ} \mathrm{C}$. IR (KBr): $3285(\mathrm{NH}), 1692(\mathrm{C}=\mathrm{O}), 1630(\mathrm{C}=\mathrm{N}), 1603,1585$ $(\mathrm{C}=\mathrm{C}) \mathrm{cm}^{-1} \cdot{ }^{1} \mathrm{H}$ NMR (DMSO-d $)$ $\delta: 2.17\left(\mathrm{~s}, 3 \mathrm{H}, \mathrm{CH}_{3}\right)$, 7.49 (d, 2h, Ar-H), 7.66 (s, 1H, H-5 of thiazole ring), 7.91 (d, 2h, Ar-H), 12.85 (s, 1h, NHCO) ppm. ${ }^{13} \mathrm{C}$ NMR

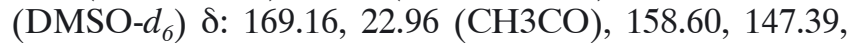
133.66, 132.66, 129.21, 127.82, 109.06, (C of thiazole and aromatic ring) ppm. MS: $\mathrm{m} / \mathrm{z}(\%)=254\left(\mathrm{M}^{+}+2\right.$, 33.20), $252\left(\mathrm{M}^{+}, 100\right)$ Anal. Calcd. For $\mathrm{C}_{11} \mathrm{H}_{9} \mathrm{~N}_{2} \mathrm{ClOS}$ (252): C, 52.28; H, 3.59; N, 11.08. Found: C, 52.11; H, 3.33; N, 11.01 .

Ethyl $\beta$-(p-acetoxyphenyl)- $\beta$-[4-(p-chlorophenyl)-thiazole2-ylacetylamino]- $\alpha$-cyano acrylate $(5)$

Yellow crystals, yield $63 \%$, m.p $105-107^{\circ} \mathrm{C}$. IR (KBr): 2224 (CN),1762, $1724(\mathrm{C}=\mathrm{O}), 1643(\mathrm{C}=\mathrm{N}), 1605,1578$ $(\mathrm{C}=\mathrm{C}), 1092,1012 \mathrm{~cm}^{-1} .{ }^{1} \mathrm{H}$ NMR (DMSO-d $\left.)_{6}\right) \delta: 1.30(\mathrm{t}$, $\left.3 \mathrm{H}, \mathrm{CH}_{3}\right), 2.10\left(\mathrm{~s}, 3 \mathrm{H}, \mathrm{COCH}_{3}\right), 2.26\left(\mathrm{~s}, 3 \mathrm{H}, \mathrm{COCH}_{3}\right)$, $4.29\left(\mathrm{q}, 2 \mathrm{H}, \mathrm{OCH}_{2}\right), 6.95-8.11(\mathrm{~m}, 9 \mathrm{~h}, \mathrm{H}$-thiazole and Ar-H) ppm. ${ }^{13} \mathrm{C} \mathrm{NMR}$ (DMSO- $d_{6}$ ) $\delta: 169.23,162.24,22.93$, $21.14\left(2 \mathrm{xCOCH}_{3}\right), 169.16,62.84,14.42(\mathrm{COOCH} 2 \mathrm{CH} 3)$, $158.62,154.48,154.43,147.93,133.64,132.87,132.66$, 129.39, 129.18, 128.84, 127.79, 123.32, 109.01, 102.77 (C of thiazole and aromatic ring), $116(\mathrm{CN}) \mathrm{ppm}$. MS: m/z $(\%)=511\left(\mathrm{M}^{+}+2\right.$, unstable $), 509\left(\mathrm{M}^{+}\right.$, unstable $)$. Anal. Calcd. For $\mathrm{C}_{25} \mathrm{H}_{20} \mathrm{~N}_{3} \mathrm{ClO}_{5} \mathrm{~S}$ (509): C, 58.88; H, 3.95; N, 8.24. Found: C, 58.63; H, 3.71; N, 8.03.

$N$-(o-acetoxyphenyl, acetoxy) methyl- $N$-(4-(p-chlorophenyl)thiazol-2-yl) cinnamide (9).

Pale yellow crystals, yield $71 \%$, m.p $160-162^{\circ} \mathrm{C}$. IR (KBr): $1766(\mathrm{C}=\mathrm{O}), 1692(\mathrm{C}=\mathrm{O}$ of amide $), 1625(\mathrm{C}=\mathrm{N})$, 1603, $1545(\mathrm{C}=\mathrm{C}), 1197,1091 \mathrm{~cm}^{-1} .{ }^{1} \mathrm{H}$ NMR (DMSO-d $\left.d_{6}\right)$

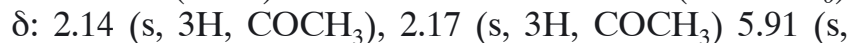
1H, OCH-N), 7.15-7.92 (m, 16h, H-thiazole and Ar-H) ppm. MS: $\mathrm{m} / \mathrm{z}(\%)=549\left(\mathrm{M}^{+}+2\right.$, unstable $), 547\left(\mathrm{M}^{+}\right.$, unstable). Anal. Calcd. For $\mathrm{C}_{29} \mathrm{H}_{23} \mathrm{~N}_{2} \mathrm{ClO}_{5} \mathrm{~S}$ (547): C, 63.67; H, 4.24; N, 5.12. Found: C, 63.36; H, 4.03; N, 5.07.

\section{LITERATURE CITED}

1. Schnurch, M., Waldner, Hilber, K. \& Mihovilovic, M. D. (2011). Synthesis of 5-arylated $N$-arylthiazole-2-amines as potential skeletal muscle cell differentiation promoters. Bioorg. Med. Chem. Lett., 21(7), 2149-2154. doi.org/10.1016/j. bmcl.2011.01.123.

2. Yadav, P.S., Devprakash \& SenthilKumar, G.P. (2011). Benzothiazole: different methods of synthesis and diverse biological activities. Int. Pharm. Sci. Drug Res., 3, 1-7.

3. Zaki, I., Abdelhameid, M.K., El-Deen, I.M., Wahab, A.H. A.A., Ashmawy, A.M. \& Mohamed, K.O. (2018). Design, synthesis and screening of 1, 2, 4-triazinone derivatives as potential antitumor agents with apoptosis inducing activity on MCF-7 breast cancer cell line. Eur. J. Med. Chem., 156, 563-579. doi.org/10.1016/j.ejmech.2018.07.003.
4. Hassan, F.A. (2012). Synthesis, characterization, antiinflammatory, and antioxidant activities of some new thiazole derivatives. Int. J. Appl. Sci. Technol., 2, 180-187.

5. El-Sayed, E.H., Moustafa, A.Y., \& El-Ata, S.A.A. (2018). Synthesis of New 2-N-Substituted Amino-5-aryl-1,3-thiazoles as Antitumor Agents. Latin Amer. J. Pharm., 37, 1594-1601.

6. Al-Ghareb, M.S., El-Hady, H.A. \& Abd-Allah, R.M. (2018). In Vitro Antitumor Evaluation of Some New Tetra Substituted 1,2,4-Triazines. Latin Amer. J. Pharm., 37, 1035-1045.

7. Minh-An, T.N., Kumar, M.A., Chang, S.H., Kim, M.P., Kim, J.A. \& Lee, K.D. (2014). Synthesis, Anticancer and Antioxidant Activity of Novel 2,4-Disubstituted Thiazoles. Bull. Korean Chem. Soc., 35(6), 1619-1624. https://doi.org/10.5012/ bkcs.2014.35.6.1619.

8. Mahmoodi, N.O., Parvizi, J., Sharifzadeh, B. \& Rassa, M. (2013). Facile Regioselective Synthesis of Novel bis Thiazole Derivatives and Their Antimicrobial Activity. Arch. Pharm. Chem. Life Sci., 346(12), 860-864. doi.org/10.1002/ardp.201300187.

9. Silverman, R.B. (1992). The Organic Chemistry Of Drug Design And Drug Action, Academic Press; London, 12, 263.

10. Pani, A., Mrongiu, M.E., Pinna, E., Scintu, F., Perra. C., Demontis, A., Manfredini, S. \& La-Colla, P. (1998). In vitro and in vivo antiproliferative activity of IPCAR, a new pyrazole nucleoside analog. Anticancer Res., 18, 2623-2630.

11. Krapcho, A.P., Menta, E., Olive, A., Didomenica, R., Fiocchi, L., Maroesch, M.E., Gallagher, C.E., Hacker, M.P., Beggiolin, G., Giullani, F.C., Pezzoni, G. \& Spinelli, S. (1998). Synthesis and Antitumor Evaluation of 2,5-DisubstitutedIndazolo[4,3-gh]isoquinolin-6(2H)-ones (9-Aza-anthrapyraz oles). J. Med. Chem., 41, 5429-5444. DOI: 10.1021/jm9804432.

12. Daidone, G., Maggio, B., Plescia, S., Raffa, D., Musiu, C., Milia, C., Perra, G., \& Marongiu, M.E. (1998). Antimicrobial and antineoplastic activities of new 4-diazopyrazole derivatives. Eur. J. Med. Chem., 33, 375-382. doi.org/10.1016/ S0223-5234(98)80004-4.

13. Kubba, A.A.R.M. \& Rahim, N.A.H.A. (2018). Synthesis and antimicrobial evaluation of new-[2-amino-4- (4-chloro-/4bromophenyl)-1,3-thiazole derivatives. J. Pharm. Res., 12(1), $145-150$.

14. de Santa, T.I., de Oliveira Barbosa, M., de Moraes Gomes P.A.T., da Cruz A.C.N., da Silva, T.G. \& Leita, A.C.L. (2018). Synthesis, anticancer activity and mechanism of action of new thiazole derivatives. Eur. J. Med. Chem., 144, 874-886. doi. org/10.1016/j.ejmech.2017.12.040. 